[May, H. (2004). Moving the Frontiers of Convention 1975-2003: An Overview of the Early Childhood Education Landscape. New Zealand Annual Review of Education, 13, 169-188]

\section{Moving the Frontiers of Convention 1975-2003: An Overview of the Early Childhood Education Landscape}

\section{HELEN MAY}

\section{Abstract:}

There has been an early childhood convention every four years since 1975. In a keynote address to the Eighth Early Childhood Convention held at Palmerston North in September 2003, the author presented an overview analysis of these conventions in the pedagogical and political landscape of early childhood in Aotearoa-New Zealand. ${ }^{1}$ The resulting convention papers can be seen as signposts, outlining the pedagogical and political issues of the time. The convention forums have been a useful platform for:

- celebrating New Zealand early childhood education

- challenging entrenched opinion

- critiquing existing policy and practice

- signalling strategic directions

- forecasting new frontiers.

This paper is an abbreviated and updated version of the keynote address. It summarises the debate and discourse on early childhood matters in Aotearoa-New Zealand from 1975 until 2003 through the medium of the conventions themselves.

$\mathrm{A}^{\mathrm{t}}$

t the first early childhood convention in Christchurch, the Director General of Education, William Renwick, was photographed for The Press (August 27, 1975). He was presenting an address, "Early Childhood Education: A Moving Frontier", to 1000 delegates. Renwick outlined the challenges of moving the frontiers of early childhood policy, and suggested that it was timely to rearrange the older Plunket slogan, "To help the mothers and save the babies."

\section{Helen May}

Instead, the "social object" of early childhood should be, "To help the babies and save the mothers" (Renwick, 1978, p. 2). Also reported were some "tongue-in-cheek" comments complaining that early childhood

voluntary organisations are often inclined to look upon bureaucrats as power-hungry, no-saying wicked fairies.... Officials can get tired of being approached as if their Minister is Father Christmas with no end to the number of goodies in his well-filled bag. (The Press, 1975, August 27)

The backdrop to these comments was an analysis of the voluntary/state partnership that was, and still is, the basis of early childhood provision. At the eighth early childhood convention held in Palmerston North in September, 2003, Howard Fancy, Chief Executive Officer of the Ministry of Education, reflected in similar fashion on the partnership, and updated the audience of 1200 on a more "hands-on" role for government, a role harking back to the yesteryears of the 1970s. The need for change was also acknowledged, but Fancy cautioned that "Successful change in education requires a long-term focus and a lot of patience - a bit like working with a toddler" (Press statement). There were delegates in the audience whose commitment to early childhood spanned the decades of both conventions, and indeed, had heard both addresses. They had themselves been activists in moving the frontiers of policy, but their patience had been sorely tried by slow-moving and/or resistant governments and policy makers. They possibly wondered whether the difficult "toddler" was also, in fact, one of the "no-saying wicked fairies!"

It is timely to appraise the years in between the first and most recent conventions, using as data the compilations of convention papers (1978 (from 1975), 1979, 1983, 1987, 1991, 1995, 1999, 2003). This legacy is an indicator of the moving frontier of the debate, discourse and convention on early childhood matters in Aotearoa-New Zealand. ${ }^{1}$

\section{Issues for Women}

The year 1975 was not only the occasion of the first early childhood convention, but also the United Nations International Women's Year (IWY). By mid-decade, many organisations and individuals, supporting equal opportunity for women, saw early childhood institutions as part of the solution to some of the problems. 
Rosslyn Noonan was the IWY national organiser at the time, and was to become a key player in the politics of early childhood over the next fifteen years. She recalled:

Nineteen-seventy-five was the crucial year because it brought together early childhood education and the women's movement which had overlapping issues.... Early childhood education people ... were beginning to analyse their inability to deliver what they saw as incredibly important - equality for all children. (cited in May, 2001, p. 123)

The event of the year was the United Women's Convention, held in Wellington with 2000 delegates from a range of women's groups. This was the backdrop to the other "event of the year", the first early childhood convention, although the occasion was more sedate in its politics. The convention was the first significant expression of what Renwick termed an early childhood "national constituency" (Renwick, 1978, p. 236).

The impetus for a convention came from the president of the New Zealand Free Kindergarten Union (NZFKU), Laura Ingram, who was concerned that early childhood services had no forum in which to share ideas (Milroy, 1983). Planning began in 1973. There was a strong kindergarten presence at the convention, but a crucial and continuing feature was the mix of academic, governmental, organisational, researcher and practitioner presence. The stated purposes of the convention were:

- to review developments in various fields of child care which had taken place in recent years and to examine important issues;

- to permit representatives from the numerous child care organisations, both voluntary and government directed, to meet together to examine problems of mutual interest; and

- to bring to the notice of as wide a range of people as possible both significant areas of concern and the kinds of knowledge which could form a useful basis for making decisions about these concerns now and in the future. (O'Rourke \& Clough, 1978, preface)

The editors of the book, based on a selection of the conference papers, claimed that future historians would regard the latter half of the twentieth century as the period in which researchers and writers could unequivocally:
- $\quad$ state the importance of the early years;

- identify the over-riding impact of the environment on children's development; and

- point to the vast improvement that early childhood education made to the achievement of young children. (1978, preface)

The editors also predicted a slow acceptance of the practical implications of the findings of early childhood research and "difficulties in communicating these findings to older generations" (p. 1). There was a wide range of papers in the book, but an underlying theme was a concern for the needs of children marooned outside the traditional "preschool" policy frameworks.

Renwick's description of the "moving frontier of early childhood" pointed to an impetus for change. Politicians in particular, and the Department of Education in general, were cautious in their response to the policy dilemmas the growing demand for childcare posed. Renwick told the audience that:

Most of us who have thought about early childhood find the circumstances of these parents so foreign to our experience, and the situation of their children so fraught with the possibility of damage, that we are ill-equipped to find satisfactory educational answers to the problems they pose. We have to break the mould of our own convictions and attitudes before we can begin to think constructively about finding solutions to situations as they are, not as we would like them to be. $(1978$, p. 236)

Early childhood activists within the "national constituency" found the translation of changing attitudes into new policies and practices frustratingly slow. One activist, childcare user and academic, Anne Smith, had arrived in New Zealand in 1974 and presented a paper at the convention, "The Case for Quality Day Care - Liberation of Children and Parents." She assured delegates that, "The development of quality day care programmes is not a challenge to the family.... Daycare is ... an additional means of support [and] may actually improve or enhance the quality of family life" (1978, p. 248). Smith argued for community-based childcare, with parent involvement, professional support and trained staff, to "be provided regardless of the family's ability to pay for it" and, "a greatly increased level of government support" (pp. 251-252).

Reflecting another view, Helen Brew, from the Federation of New Zealand Parents' Centre, presented a paper on parenthood and the 
importance of the mother's role in society. Parents' Centre, a radical organisation in the 1950s was, in the 1970s, taking a cautious stance to the idea of childcare. Brew (1978) stated her concern with

some of the more vociferous Women's Liberationists who dominate the mass media [where] there has been...an enormous "put down" of the value of the ordinary devoted mother who is staying at home caring for her children....Mothers are [now] encouraged to opt out from mothering their children to join the male rat race and leave small children for long periods in group care so their mothers can be "free". (p. 47)

Brew was, nevertheless, arguing a strong case for parents, especially mothers, to be part of a "participatory democracy" in which their voices were heard and not ignored.

These polarised viewpoints continued to strike sparks off each other throughout the 1970s and early 1980s. The 1984 Labour government initiated new policy directions for childcare, culminating in the 1989 Before Five reforms (Lange, 1988) that established integrated early childhood policy. Fourteen years onwards there are still residual industrial and professional issues unresolved (Mitchell, 2002).

\section{International Contexts}

From the start, each convention committee invited international speakers to update the early childhood community on overseas trends and issues. For the second convention, in 1979, Marie Bell chaired the organising committee. She suggested inviting Urie Bronfenbrenner from the USA and, moreover, rang him on the spot, recalling that, "It was bit like calling God!" (personal communication). He was delighted to accept and his presence was a great success. Bronfenbrenner introduced New Zealand educators to his now famous theory of The Ecology of Human Development (1979a). This positioned child development within a broader social and cultural context, beyond its older psychological frame of mother-child relationships.

The second convention, like the first, had a wider political context. Marie Bell offered to run two consciousness-raising workshops for women: "Guilt the great controller" and "Assertiveness" - 630 women enrolled! The year 1979 was also the United Nation's International Year of the Child (IYC). A Committee for Children was appointed to orchestrate events, and early childhood groups and organisations buzzed with activity. The IYC Report made recommendations on a broad range of issues for children, including a strong endorsement for more inclusive early childhood policies. A "cumulative discourse", started earlier in the decade with a few "stirrers", was now gaining momentum (Meade, in May, 2001, p. 122) although it was not successful in effecting real policy shifts.

At the convention Bronfenbrenner told delegates:

If the Year of the Child in your society or mine is not the year of the parent ... the year of the pre-school, the year of the school, the year of the neighbourhood ... if it is only the Year of the Child alone then it will be a year of loneliness for children and an ill one for their future and ours. (1979b, p. 20)

Bronfenbrenner argued that society needed to care more for the carers of children. His visit was timely in New Zealand. He was suggesting a theoretical framework that encompassed diverse family styles of childrearing that existed within a widening social and cultural network of relationships and amidst changing political and economic structures (Bronfenbrenner, 1979a). Different early childhood services could find a place and a role, whereas earlier developmental theories had judged particular early childhood institutions as acceptable or unacceptable according to the time spent by children in the daily presence of their mothers. The "moving frontier" of early childhood services was extending beyond the provision of preschool education for the benefit of the child alone. Now a range of services could provide "caring support" to children, families and communities.

A pattern began whereby the presence of the likes of Urie Bronfenbrenner in 1979, Irving Lazar in 1983, and David Weikart in 1987, was promoted to advance the causes of early childhood politics. Meetings for the international experts with academia, government officials, politicians and the media were carefully orchestrated, often by the Department of Education. At the time of the fourth convention in 1987 in Wellington, the Labour government was mid-term. Childcare had been moved into the Department of Education, but there was no comparable funding for children in childcare, and kindergartens, too, were under-funded. The visit from David Weikart, founder of the Highscope Preschool Project in the USA, was opportune. His longitudinal study demonstrated lasting social and educational gains to the participants in quality early childhood (Sweinhart, Weikart \& Larner, 1986). Weikart told the audience, "You are more effective 
crime fighters than anyone in the country. You are the most effective people in the nation for reducing teen pregnancy" (Waikato Times, 1987, January 30 ). Weikart's message was that the long term savings to society were a profitable return on the investment in early childhood (Weikart, 1987). The media were interested. The Dominion (1987, February 3) reported from the convention that, "Mr Marshall urged early childhood workers to help him battle Treasury for more education dollars and convince the Minister of Finance, Roger Douglas, of the value of early childhood education." This battle for funding still continues, after some skirmishes were won (in 1989) and then some lost (in 1991).

Some women however, were unhappy with the "boys talk" surrounding conventions. At the 1987 plenary, a recommendation to the fifth convention was that "No overseas speakers were necessary" (Proceedings of the Fourth Early Childhood Convention, 1987, p. 3). For the 1991 Dunedin convention, Anne Smith and the organisers determined a different image was necessary (Gold, Foote \& Smith, 1991). Not only would local keynote speakers be given equal billing, but the international speakers would be women. The mix was electrifying and the air was full of political fury. The Labour government had been voted out of office only a year after the Before Five reforms had been bedded in, and the new National government was intent on dismantling aspects of them. The keynote line-up included the "renown" in New Zealand's early childhood sector. Anne Meade and Anne Smith, who were in to their third decade of activism, and unionist Clare Wells, all presented perspectives on the impact of the recent education reforms. Arapera Royal-Tangaere (1991) and Teupoko Morgan (1991) outlined the respective situations of indigenous Maori children and those with a Pacific Nations heritage. Then there were: Lilian Katz and Corallee Howes from the USA, Anne Stonehouse from Australia and Helen Penn from the United Kingdom - four international women "greats" whose research and policy insight was a cornerstone for advocacy in this country as well as others. Subsequently, in 2003, Elly Singer from the Netherlands and Janet Gonzalez-Mena from the US were keynote speakers, both "greats" in developing new cultural and developmental understanding of early childhood practice (Gonzalez-Mena, 2003; Singer, 2003).

\section{Cultural Politics}

There was no significant presence of Maori women at the first convention in 1975. The exception was an unpublished presentation by Mary [Miria] Penfold on "Child Rearing Practices of the Maori in Traditional Society" (New Zealand Free Kindergarten Union, 1975, June). Other commentary on Maori children was framed around issues of disadvantage. David Barney's (1978) research summary of his earlier book Who Gets to Preschool? (Barney, 1975) identified the barriers to participation for Maori children. Jane Ritchie (1978a, 1978b) reported on Te Kohanga, the University of Waikato preschool experiment for disadvantaged Maori children, which was attracting interest and concern.

Prior to the second convention, Bronfenbrenner and his wife stayed on the Orakei Marae. Delegates were welcomed to Christchurch by children from Te Kohitangi Maori group. In a series of popular workshops, Frances Smith from Christchurch and Hine Potaka, with women from the Awhina Whanau programme, introduced delegates to the use of natural resources, Maori legends and waiata in early childhood programmes. A moving presentation at the close of the Convention called for a stronger acknowledgement of a Maori presence in early childhood education.

Thus, in 1983 the third convention left its roots in Christchurch and was held at Turangawaewae Marae, Ngaruawahia. Leone Shaw (1983, p. 146) paid public tribute to Bronfenbrenner:

[In 1979] he thanked New Zealand for giving him the gift of two cultures. He had been surprised and delighted to find the country's two main culture streams were so strong. He saw the value of the marae to all of us ... His prompting is one of the reasons for us being here. I think also that we have a desire to understand ourselves better.... The convention ... has been bi-cultural in content, attendance and form.

Maori issues were to the fore. The fledgling Kohanga Reo movement had burst onto the scene only a year earlier. Dr Tamati Reedy, Assistant Secretary for the Department of Maori Affairs, accompanied the delegates onto the marae for a powhiri.

The gift from the third convention was the logo, its whakatauki, Kahikitea Tu i Te Uru, and the Tuhoe waiata, composed by Hirini Melbourne, was later sung at all conventions and many early childhood events: 


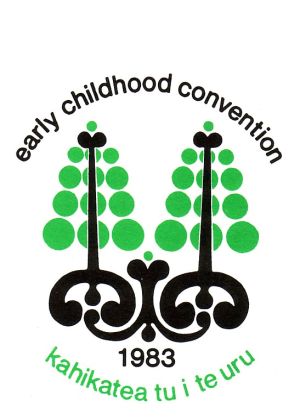

E tu kahikitea,

E whakapae ururoa

Ahi mai awhi atu

Tatou tatou $E$

In past times the giant kahikitea trees were rarely seen growing alone because of the protection afforded by their entwining root structure. It has since been explained on the fly-leaf of convention proceedings, that:

With this supportive environment the kahikitea trees grow straight and tall; similarly our understanding of the ideal of young children to grow and mature includes others of their own kind for stimulation, development, strength and survival.

Hamilton Teachers' College lecturer, Colin Gibbs, designed the logo. Convention co-convenor Miria Pewhairangi (1983, p. 150) told national radio interviewer, Haare Williams that:

[The logo] is referring to the Maori and pakeha groups coming together and standing together and supporting one another. It also has the connotation of the many and diverse early childhood groups coming together... My belief ... is that the bi-cultural theme has been firmly planted.

Subsequent conventions have grappled with the possibilities and problems of realising this dream. In 1983, Pewhairangi noted that, by the next convention in Wellington, "the first kohanga reo babies will be poised to go to school" (p. 156). At the 1987 convention Kathie Irwin presented a challenge to the early childhood sector:

For many, Kohanga Reo is being heralded as "the solution" for our people, I find that to be a very interesting observation. I have come to ask a question of all of you - if Kohanga Reo is the solution, then what is the problem? What is the problem? And what role do each and every one of you play in perpetuating that problem.... The problem, I believe, has to do with power. (Irwin, 1987, p. 27)

Seventeen years later, the themes are still current despite the best efforts of many in the early childhood sector to address issues both bicultural and multicultural. Irwin returned in 2003 as a keynote speaker to report on, "Te Kohanga Reo 21 years on" - and believing it to be a "movement that still inspired" (2003, p. 28). She talked about the original vision of

... futures in which being Maori made a significant contribution to the nation building of Aotearoa ... [and claiming that] those futures are still about ... Maori and speakers of te reo Maori. Maori and achievers. Maori and entrepreneurs. Maori and global citizens. Maori and success. (p. 29)

These were themes addressed by Mason Durie in the opening address to the 2003 convention. He created a new "metaphoric map" for early childhood teachers, one that charted the foundations of cultural identity - Te Pae Mahutonga - the Southern Cross constellation of stars. He elaborated:

The four central stars of Te Pae Mahutonga can be used to represent the four key foundations of Maori culture in modern times: Wairoa, access to te ao Maori (the Maori world); Mauriora, access to the natural environment; Toiora, positive life styles; and Te Oranga, participation in wider society. The two pointers symbolise the two key capacities which underpin progress in positive Maori development: effective leadership. Nga Manukura, and autonomy, Te Mana Whakahaere. (Durie, 2003, p. 12)

Durie's map focussed on Maori, but he suggested that it could have relevance to all cultures of New Zealanders.

Alongside the presence of a Maori early childhood pedagogy, the cultural landscape of early childhood services had been similarly challenged and changed by the emergence of Pacific Islands language centres (Mara, 1995). At the 1991 Dunedin convention, Teupoko Morgan, a key champion of Pacific Island early childhood programmes, outlined the success of the recently completed three-year Anau Ako Pasifika home-based early childhood project. Its emphasis on Pacific languages, cultures and resources was both a stepping stone into early childhood education, as well as a support to the growing number of Pacific Island centres (Morgan, 1991).

Teupoko Morgan and Arapera Royal-Tangaere, also a keynote speaker in 1991, both acknowledged the contribution of the Early Childhood Development Unit (later ECD). This new education agency described by Royal-Tangaere as, "the baby of the Meade Report" (1991, p. 91) had been established in 1989 as an early childhood advisory and 
support service. Its structure reflected both Maori and Pakeha perspectives as Treaty partners, as well as including a strong Pacific strand. In the event the fuller dream embodied in ECD was curtailed through government cutbacks and policy shifts. The eighth convention, in 2003, was the swansong of ECD, whose work and staff were "integrated" into the Ministry of Education one week later.

\section{Curriculum Debates}

Conventions have provided an academic and professional forum for debate concerning curriculum. An ongoing theme has been the value and place of play, particularly in the light of shifting pedagogical and political positions. This was particularly evident at the 1975 convention.

Playcentre leader and writer, Gwen Somerset, presented a plea for the value of make-believe play for young children. Citing both Piagetian, cognitive rationales and Freudian, psychological rationales, Somerset was convinced that the learning of any skill was "a joyful experience when novelty and interest are present" (1978, p. 136). Mindful of increasing interest in more structured learning programmes, Somerset (1978, p. 137), warned of the errors of education systems that:

Ram it in

Cram it in

Children's heads are hollow

Slam it in

Bang it in

Still there's more to follow!

Somerset positioned the place of play differently from Jane Ritchie who asked the question, "Children in Need: Is Play Enough?" for Maori children. Ritchie (1978a, p. 181) strongly defended her languageenriched programme, begun in 1974:

Simply to provide them with the normal range of developmental activities and to offer them the unstructured play programme of the usual New Zealand pre-school would not be sufficient for them to overcome their language and cognitive disadvantages.

The debate was mainly academic. Professional opinion was not inclined to reconsider the "free-play" focus of kindergarten and playcentre programmes. Massey university lecturer Chris Smyth (1978) also questioned the play-based focus in New Zealand. He reported on a statement from the 1974 UNESCO conference on the development of children from birth to six years:

Research has shown that a structured curriculum can be effective in achieving certain educational objectives. Structured curricula must not be arbitrarily imposed by teachers but must emerge from a deep understanding of how children learn and develop. (UNESCO, 1974, p. 12, cited in Smyth, 1978, p. 158)

Smyth (p. 163) acknowledged that there would be little support for the UNESCO position amongst the New Zealand preschool movement: "Those who advocate placing some intentional structure on the curriculum are sometimes accused of creating an artificial environment." However, Smyth saw all preschool environments as artificial, suggesting instead that: "The choice is between an artificial environment which is planned and an artificial environment which is accidental and often unrecognised. The former is surely preferable." Smyth claimed that more variety and richness of programmes, and indeed "planned structure" could "revitalise our early childhood curriculum" (pp. 163-164). Quoting the UNESCO study, he suggested that, "Teachers should conceive of their role in a new way."

During the 1990s, against a backdrop of school curriculum reform, curriculum issues did engage the early childhood profession. The Dunedin 1991 Convention was a forum, for Margaret Carr and myself, to consult and showcase some initial thinking on the proposed early childhood national curriculum guidelines (Carr \& May, 1991). In 1991 there was no Te Whaariki, but a belief that the Treaty of Waitangi principles necessitated the inclusion of a distinct Maori pedagogy. We talked about "multiple curricula", acknowledging too the presence and practice of Pacific Islands, home-based and special needs curricula. The 1975 preschool landscape had changed by 1991. The pedagogical landscape had also shifted, and socio-cultural contexts of learning were positioned alongside older developmental psychological contexts.

In the intervening years, older debates on structure versus free play had been overlaid by new understandings of children's learning and thinking. The focus of the curriculum project moved beyond the traditional activities of children's play in preschool settings, to focus more on the children and the role of adults in supporting children's learning and development in a variety of contexts and ways. This was not intended to devalue the place of child-initiated play, but to suggest 
that teachers become more engaged in creating environments in which all children "learn how to learn". This was a theme addressed by Anne Meade in a keynote address to the 1995 Auckland convention:

For children to "Be More" we - the adults - need to "do more"... I have been concerned for over a decade about the possibility that early childhood services have been selling children short, that we could be "doing more". (1995, p. 50)

Meade was urging the importance of extending children's thinking. Convention presentations in both 1995 and 1999 reflected the heightened interest in children's learning. They document the ongoing implementation and impact of Te Whaariki on the early childhood landscape in terms of pedagogy, research and practice. Very little of it, however, contained critical comment. It was therefore appropriate that at the 2003 convention Weaving Te Whaariki was launched (Nuttall, 2003). New Zealand and international authors provide insight and critical reflection on a curriculum exactly a decade after its first release. There was a mood of confidence and challenge at the convention that it was timely for the sector to consider moving "beyond Te Whaariki".

\section{Political Directions}

This final section revisits the "moving frontier" of early childhood policy that Renwick described in 1975, from a policy standpoint. The slow pace of change was a concern. At the fourth convention in Wellington in 1987, the first term of the David Lange Labour Government was almost ending. In a testy keynote presentation, I reflected on the difficulties even with "friends" in power:

They have listened to the early childhood constituency. We are on first name terms. We talk of co-operation. We don't have to wear our pearls anymore, but does it work?... The blueprints are all there but there are limits to what you can do with beautiful policy if you don't get the funding. (May, 1987, p. 31)

Such sentiments have a parallel to the political situation of 2003. It is the second term of a Labour-led Government. A ten-year strategic plan, equity funding for selected centres, pay equity for kindergarten teachers, a commitment to a qualified workforce, and six centres of innovation, are significant achievements. However, the sector is still awaiting clues to the funding package intended to address the acute under-funding in the sector, inequity of provision and access, and most significant, pay equity for all qualified teachers.

I have not been alone in using the convention podium as a political platform for stating concern with the intransigence of the policy frontiers. In the event, the Before Five (Lange, 1988) policies addressed many of the funding and policy concerns outlined earlier at the 1975 convention. Unfortunately, the 1991 convention did not celebrate these gains. Instead, it was necessary to protect the Before Five gains from being dismantled by the new National government. Anne Meade told delegates:

What seems to be happening in 1991 is a re-run of earlier ideological struggles, with early childhood as the "meat in the sandwich". Early childhood was, and is again an arena where ideological conflict is being worked out... Could it be that the gains made by early childhood education are too "ideologically expensive"?... Early childhood educators demonstrate the falseness of many (most) claims made by the New Right. We get no thanks for our collective success - only reviews and more reviews. (1991, pp. 34-35)

Clare Wells described a similarly bleak picture, but suggested that the sector was sufficiently resilient to withstand the setbacks:

The reassuring aspect, however, is that the commitment [by the sector] does exist, and for my part understanding and acknowledging the influences on us as workers in early childhood may provide a temporary set-back, but knowing what we do ... we will have the energy to carry on to achieve goals so recently within our grasp. (1991, p. 126)

The "temporary set-back", however, lasted throughout much of the 1990s, although at the seventh convention in Nelson in 1999, the Minister of Education, Nick Smith (September 29), gave an upbeat appraisal of National's achievements. "We have so much we can be proud of in our early childhood sector. We have innovation. We have standards. We have diversity. And our children are the winners." There had been a considerable increase in participation during the decade but funding levels to centres did not reach the levels promised in the Before Five reforms.

In 1999 a new Labour-led government established the Strategic Plan Early Childhood Education (SPECE) working party that recommended a more hands-on government role. Accessible, 
affordable and quality early childhood services for all children were the goals A visionary solution of "a universal entitlement to a reasonable amount of free, high quality early childhood education" was presented to the government (Strategic Plan Working Group, 2001a, p. 5). The reaction of the Minister of Education, Trevor Mallard, was that this was "blue skies thinking", and the working group was told to be more fiscally responsible (Mallard, 2001). SPECE's final report still held to the view that, "Early childhood education ... be positioned to become part of the wider education sector - alongside schools - where children are accorded a universal entitlement to free (or almost free) education" (Strategic Plan Working Group, 2001b, p. 4). It was argued that this would merely position New Zealand alongside most of their OECD partners. The government's response in Pathways to the future: Nga huarahi arataki. A ten year strategic plan for early childhood education (Ministry of Education, 2002) made no mention of "free early childhood education".

\section{Conclusion}

The policy frontiers of early childhood have shifted since Renwick presented his address to the first convention. Some sections of the old frontier have crumbled away but others are still proving resistant. The cultural landscape and the balance of the diverse provision in 2003 were barely conceivable in 1975 . However, the debate concerning the extent of tax-payers' money available to the sector is still alive. Renwick's characterisations of voracious early childhood voluntary agencies, "blithely" beleaguering maligned "officials", "bureaucrats" and politicians for "tax-payers money" probably still apply.

Gains to the sector have always required collective, concerted and sometimes strident advocacy. Conventions have provided a suitable podium and platform for such advocacy. Amongst the remits placed on record at the eighth early childhood convention was a call for

- Pay equity for teachers in childcare, and

- A universal entitlement for all children to a "reasonable amount" of free early childhood education.

The arguments have been made in other forums as well. These are important frontiers to shift in a quest for an early childhood sector truly equal with the school sector. At the ninth convention to be held in
Rotorua in 2007 it is hoped that, (using the words of Renwick) the "wicked fairies" and "Father Christmas" will have prioritised the interests of the youngest as significant beneficiaries of "tax-payers money". Or (using the words of Fancy), that the "toddler" will have gone to school and patience will have been rewarded!

\section{Note}

1. Aotearoa is the name given by indigenous Maori to the land that Europeans (re)named New Zealand.

\section{References}

Barney, D. (1975). Who gets to preschool? Wellington: New Zealand Council for Educational Research (NZCER).

Barney, D. (1978). Availability of pre-school education. In B. O'Rourke \& J. Clough (Eds.), Early Childhood in New Zealand (pp. 248-252). Auckland: Heinemann Educational Books.

Brew, H. (1978). The making of a parent. In B. O'Rourke \& J. Clough (Eds.), Early Childhood in New Zealand (pp. 39-52). Auckland: Heinemann Educational Books.

Bronfenbrenner, U. (1979a). The ecology of human development. Harvard, Mass: Harvard University Press.

Bronfenbrenner, U. (1979b). Who cares for children? Papers for the Second Early Childhood Care and Development Convention (pp. 20-25). Christchurch.

Carr, M., \& May, H. (1991). National curriculum guidelines for early childhood Aotearoa/New Zealand: A philosophical framework for development. In M. Gold, L. Foote, M. \& A. Smith (Eds.), Proceedings of the Fifth Early Childhood Convention (pp. 212-235). Dunedin.

Durie, M. (2003). Te pae mahutonga: A navigational guide for the promotion of secure identity and best outcomes for Maori children. Proceedings of the Seventh Early Childhood Convention, Vol. 1 (pp. 9-16). Palmerston North.

Fancy, H. (2003, September 23). Address presented at the Eighth Early Childhood Convention, Palmerston North.

Gold, M., Foote, L., \& Smith, A. (Eds.). (1991). Proceedings of the Fifth Early Childhood Convention, Dunedin. 
Gonzalez-Mena, J. (2003). Bridging cultures with understanding and sensitivity. Proceedings of the Eighth Early Childhood Convention, Vol. 1 (pp. 17-26). Palmerston North.

Irwin, K. (1987). The pakeha response to Kohanga Reo. Proceedings of the Fourth Early Childhood Convention (pp. 27-30). Wellington.

Irwin, K. (2003). Te Kohanga Reo 21 years on: Where to now? Proceedings of the Eighth Early Childhood Convention, Vol. 1 (pp. 27-45). Palmerston North.

Lange, D. (1988). Before Five. Early childhood care and education in New Zealand. Wellington: Government Printer.

Mallard, T. (2001, July 10). Speech notes. Victoria University of Wellington.

Mara, D. L. (1995). "Te Puai No Te Wahine": Pacific Island education policy and education initiatives in Aotearoa/New Zealand, a critique. Unpublished MLitt thesis in Education, University of Auckland.

May, H. (1987). The politics of provision and funding. Proceedings of the Fourth Early Childhood Convention (pp. 31-34). Wellington.

May, H. (1999). Mapping the landscape of the "Century of the Child". Proceedings of the Seventh Early Childhood Convention, Vol. 2 (pp. 27-42). Nelson.

Meade, A. (1991). Boffins in early childhood services. In M. Gold, L. Foote, \& A. Smith (Eds.), Proceedings of the Fifth Early Childhood Convention (pp. 55-67). Dunedin.

Meade, A. (1995). Meaningful or trivial? Quality early childhood education from the eye of the child. Proceedings of the Sixth Early Childhood Convention, Vol. 1 (pp. 50-62). Auckland.

Milroy, P. (1983). Transcribed interview with national radio broadcaster Haare Williams. Papers for the Third Early Childhood Convention (pp. 150-153). Ngaruawahia.

Ministry of Education (2002). Pathways to the future: Nga huarahi arataki. A ten year strategic plan for early childhood education. Wellington: Learning Media.

Morgan, Teupoko (1991). Anau Ako Pasifika project: Pacific early childhood education project. In M. Gold, L. Foote, \& A. Smith (Eds.), Proceedings of the Fifth Early Childhood Convention (pp. 68-76). Dunedin.
New Zealand Free Kindergarten Union. (1975, June). Early Childhood Convention. Kindergarten.

Nuttall, Joce (Ed.). (2003). Weaving Te Whaariki: Aotearoa-New Zealand's early childhood curriculum document in theory and practice. Wellington: New Zealand Council for Educational Research.

O’Rourke, B., \& Clough, J. (Eds.). (1978). Early childhood in New Zealand. A selection of presentations from the 1975 early childhood convention. Auckland: Heinemann Educational Books.

Papers for the Second Early Childhood Development and Care Convention. (1979). Christchurch.

Papers for the Third Early Childhood Convention. (1983). Ngaruawahia.

Pewhairangi, M. (1983). Maori self-assertion in preschool education 1961-82. Papers for the Third Early Childhood Convention (pp. 104-105). Ngaruawahia.

Proceedings of the Fourth Early Childhood Convention. (1987). Wellington.

Proceedings of the Sixth Early Childhood Convention. Vols 1 \& 2. (1995). Auckland.

Proceedings of the Seventh Early Childhood Convention. Vols. 1 E 2. (1999). Nelson.

Proceedings of the Eighth Early Childhood Convention. Vols. 1 \& 2. (2003). Palmerston North.

Renwick, W. (1978). Early childhood education: A moving frontier. In B. O'Rourke \& J. Clough (Eds.), Early childhood in New Zealand (pp. 231-237). Auckland: Heinemann Educational Books.

Report of the Select Committee on Women's Rights. (1975). The role of women in New Zealand society. Wellington: Government Printer.

Royal-Tangaere, A. (1991). "Kei Hea Te Komako e Ko?" Early childhood education, a Maori perspective. In M. Gold, L. Foote, \& A. Smith (Eds.), Proceedings of the Fifth Early Childhood Convention (pp. 81-99). Dunedin.

Ritchie, J. (1978a). Children in need: Is play enough? In B. O'Rourke \& J. Clough (Eds.), Early childhood in New Zealand (pp. 179-191). Auckland: Heinemann Educational Books.

Ritchie, J. (1978b). A chance to be equal. Whatamongo Bay: Cape Catley. 
Shaw, Leone. (1983). Summary address to Early Childhood Convention. Papers for the Third Early Childhood Convention (p. 146). Ngaruawahia.

Singer, E. (2003). Peacemaking among young children in multicultural child centres. Proceedings of the Eighth Early Childhood Convention, Vol. 1 (pp. 73-86). Palmerston North.

Smith, A. (1978). The case for quality day care in New Zealand Liberation of children and parents. In B. O'Rourke \& J. Clough (Eds.), Early childhood in New Zealand (pp. 248-252). Auckland: Heinemann Educational Books.

Smith, N. (1999, September 29). Address to the Seventh Early Childhood Convention, Nelson.

Smyth, C. (1978). Curriculum in early childhood education. In B. O'Rourke \& J. Clough (Eds.), Early childhood in New Zealand (pp. 158-165). Auckland: Heinemann Educational Books.

Somerset, G. (1978). Some environmental factors influencing innovation and fantasy in early childhood. In B. O'Rourke \& J. Clough (Eds.), Early childhood in New Zealand (pp. 136-141). Auckland: Heinemann Educational Books.

Strategic Plan Working Group. (2001a). Consultation document for the development of the strategic plan for early childhood education. Wellington: Ministry of Education.

Strategic Plan Working Group (2001b). Final version: Strategic plan for early childhood education. Wellington: Ministry of Education.

Sweinhart, L. J., Weikart, D., \& Larner, M. (1986). A Report on the High/Scope Preschool Curriculum Comparisons Study: Consequences of three preschool curriculum models through age 15. Ypsilanti, MI: High/Scope Educational Research Foundation.

UNESCO. (1974). Final report of the meeting of experts on the psychological development of children and implications for the education process (p. 12). Illinois. Cited in C. Smyth (1978). Curriculum in early childhood education. In B. O'Rourke \& J. Clough (Eds.), Early childhood in New Zealand (p. 158). Auckland: Heinemann Educational Books.

Weikart, D. (1987). Keynote Address. Proceedings of the Fourth Early Childhood Convention (pp. 11-21). Wellington.
Wells, C. (1991). The impact of change - against the odds. In M. Gold, L. Foote, \& A. Smith (Eds.), Proceedings of the Fifth Early Childhood Convention (pp. 115-127). Dunedin.

\section{The author}

Helen May is Professor of Early Childhood Education at Victoria University of Wellington. She has recently been Head of School of Education, but has now returned to her earlier position of Director of the Institute for Early Childhood Studies. She is the author of several books and many articles on the history and politics of early childhood education 